\title{
The Influence of the Local Community Post Conflict Intervention Measures on Reconstruction of Public Primary Teacher Training Colleges in South Sudan
}

\author{
Peter Ador Riak Nyiel ${ }^{1}$, Daniel Komo Gakunga ${ }^{2} \&$ Rosemary Khitieyi $^{3}$ \\ ${ }^{1}$ Department of Educational Administration and Planning, University of Nairobi, Nairobi, Kenya \\ ${ }^{2}$ Department of Educational Foundations, University of Nairobi, Nairobi, Kenya \\ ${ }^{3}$ Department of Educational Administration and Planning, University of Nairobi, Nairobi, Kenya \\ Correspondence: Peter Ador Riak Nyiel, Department of Educational Administration and Planning, University of \\ Nairobi, Nairobi, Kenya.
}

Received: October 23, 2020

Accepted: February 23, 2021

Online Published: March 25, 2021

doi:10.20849/jed.v5i1.879

URL: https://doi.org/10.20849/jed.v5i1.879

\begin{abstract}
This study assessed the influence of local community intervention measures on reconstruction of public teacher training colleges in South Sudan. The study adopted a descriptive cross-sectional survey design and a total of 1953 respondents including the principals, tutors and teacher students from 3 registered and operational teacher training colleges in South Sudan. Stratefied random sampling technique was used to select 321 respondents as the sample size. The study collected primary data using questionnaires and interview guides. The analysis of the colelcted data was conducted using descriptive statistics like frequencies and percentages. Besides descriptive statistics, the study also used inferential statistics including correlation and regression analysis. The study established that local community intervention measures $(\mathrm{p}<0.05)$ were all significant. Therefore, the study rejected the formulated hypotheses in favour of the alternative hypotheses since their p-values were all less than 0.05 as 5 per cent was considered as the level of significance in the study. The study concluded that all local community intervention measures had positive and significant influence on reconstruction of public teacher training colleges. The study recommended that the Ministry Education in South Sudan work in close collaboration with all the stakeholders in the field of education as far as reconstruction of training colleges is concerned.
\end{abstract}

Keywords: local community, post conflict intervention measures, reconstruction public primary teacher training colleges and South Sudan

\section{Introduction}

Attacks on the educational system of a country encompass a wide range of violations especially those exposing children to risk thereby denying them access to education which is one of the basic needs (Human Rights, 2015). It comprises of attacks on learning facilities and centers, on learners and those teaching them. It also includes the militarization of the above where schools are converted into Military or Police barracks, intimidation of parents, teachers and their children or students; and at times, the forcible recruitment of students/pupils as child soldiers (Human Rights, 2015). These attacks result in children dropping out or absenting from school, reduced/interruptions of learning hours and destruction of school buildings and materials (Lansford, Dodge, Pettit \& Bates, 2016). Examples of countries which have experience such situations includes Nepal, Afghanistan, Iraqi, Rwanda, Liberia and South Sudan.

According to Schauer et al. (2018), there are ongoing emergency educational intervention in Iraq and Afghanistan for instance; where foreign donors have pumped in huge funds in support of the educational system; setting the infrastructure necessary for learning environment, equipping possible teachers with necessary skills and competency to perform, availing learning materials which are to be used by learners and other learning facilitation materials across the two countries but to no great effect. Insecurity remains a challenge, particularly the threat posed by religiously inspired armed groups of ISIS and Taliban respectively, who are opposed to a secular education curriculum (UNESCO's 2013). The infrastructure of in-services teacher training institutes in Iraq is poor with limited capacity of planning, monitoring and managing comprehensive program (Johnson, 
2016). UNESCO has been helping the Ministry of Education to create a critical mass of highly qualified teacher trainers. In Afghanistan, The Ministry of Education 2006-2010 strategic plan, the ministry recorded to have facilitated training for those already employed and those yet to be employed who add up to more than 34,000 teachers and deployed more than 137,000 teachers to the schools (Pherali \& Sahar, 2018). The major objectives for the strategic plan was to come up with a structure and system that would enable training of about 232,000 teachers for both primary and secondary levels, finance construction and rehabilitation of more than 30 colleges where teachers are trained across the country, Equip and deploy more than 2100 trainers to train teachers in provision of ongoing in-service training besides other support services extension to teachers.

The Republic of Rwanda has proved to be a good example after strongly coming out of crisis and restructured education sector (UNICEF, 2015). In 1996, education sector was allocated a share of 15 percent of which 65.1 percent was for primary education, 15.5 per cent for secondary education, 9.5 per cent to higher education and the reminder 9.9 per cent covering other services. This can be taken as an indication how important primary education. The number of pupils enrolling in primary school steadily rose from 942,729 in 1994 to 2,019,991 (214 percent) in 2006 on the other hand raising the demand of primary school teachers (MoE, 2007).

For effective conflict intervention through using the education system; there is need to focus on training of teachers as the driver of the education system and as the ones who will ensure effective education system that yields positive results. For instance, Feuer, Hornidge, and Schetter (2013) shared that education was one way of post-war recovery for the youths and younger generations, as it gave them something to do than idling around. Education creates hope in the learners and this is only made possible by having trained teachers inside the system to be able to handle a wide range of conflict-affected contexts, such as per capita income, levels of violence, and types of access regime, as shared by Berdal (2009).

Existing evidence point out that basic education displays more resilient characters in times of conflict as compared to the elementary and tertiary level education largely because of the capacities of the local communities to come up with strategies that would primary learning centers to continue with operations as the infrastructure is destroyed in conflicts (Buckland, 2005; Rose \& Greeley, 2006; Davies, 2009) (MOHE/IIEP, 2004). The case for teacher training is neglected and not prioritized within post-war reconstruction efforts. Most of the efforts and resources goes to primary and secondary schooling, while failing to understand that teachers and learning is one and the same thing. The two aspects complement each other, and to having a functioning education system, the teachers need to be well trained.

According to the UNHCR report and them working together with INEE and GEC, the refugee children and young people want to be able to go to school and learn, meet new friends in the learning institutions, learn and play and meet teachers; such that they can forget and begin on the healing and reconstructive phase of their lives after the many years of conflicts. The learning environment symbolizes a turnaround point from the traumatic experiences of being displaced, loss of property, family and friends and death of the people they knew of during the conflict that has lasted two decades (Loh \& Teo, 2016). UNHCR calls for better coordination throughout the education system, simply through training of teachers who eventually can positively impact the crisis-affected children and youths are able to rebuild their lives again. There should be effective and sound resource usage after the conflict rendered them desolate and useless and alignment of the teacher trainings, their deployment and placement in schools in the hope of rebuilding the education system in South Sudan (Ajieng, 2018). Furthermore, improved coordination between humanitarian responses and development programming will also help to ensure that education services are available and have the capacity to respond to the complex needs of refugee learners. It was against this background that the study sought to determine the influence of post conflict intervention on reconstruction of public teachers' training colleges in South Sudan.

\section{Statement of the Problem}

South Sudan has witnessed conflict for many decades; the crisis in South Sudan has no doubt affected the education sector (Al-Salem, Herricks \& Hotez, 2016). A report by UNESCO Institute for Statistics (UIS) on October 2014 showed that the student-to-teacher ratio is 50:1 with only 44 percent trained teachers. The report further indicated that South Sudan was in need of 79,000 teachers according to UNESCO. UNICEF in its 22nd October 2014 gave a similar report showing South Sudan's education system plagued by critical gaps including lack of trained teachers (40 percent). UNICEF calls for extraordinary efforts in order for South Sudan to realize universal primary school Millennium Development Goal 2 and sequence realization of the United Nations Sustainable Development Goal 4.

Prolonged cases of conflicts and war in some regions of the world, call for education and trainings as an intervention and use it to reconstruct and recover the economy and social well-being for the people (Piplani \& 
Talmadge, 2016). If education has a positive influence, then it can only be effective after having well-trained teachers. Therefore, it is important to be able to link the teacher training colleges and the quality of teachers with what the learners gain as a means of conflict intervention and reconstruction of the systems. Looking at the cases of Afghanistan, Liberia and Rwanda where these countries experiences lengthy periods of conflicts and wars; the use of education to resolve the issue has been discussed. As such after any conflict, normalcy is usually preferred by all stake holders, however, the effectiveness of such intervention measures by various stakeholders are often faced by hosts of other challenges, that consequently affect effective teacher training and the education system. South Sudan as country has only seven (7) public primary teachers training colleges with only two functioning. This is a dangerous indication that unless the government of South Sudan invest in Teacher training and development, it will not realize its vision 2040 of producing qualified manpower and people who accept and appreciate diversity. The teacher training is critical in any recovery process especially with the situation in South Sudan (Lasater, 2016). This is because if teachers are not well trained, the learners will not be able to get quality education and this will adversely affect the entire education system. Ultimately, the entire process of recovery and reconstruction may not be realized. Therefore, to achieve reconstruction and recovery, a strong fight against literacy need to be a priority, as basic education plays an important role because it produces the majority of workforce (Smidt, 2020). The knowledge, skills and desirable attitude are built right from the basic education by a qualified teacher. Without proper and good basic education, all this values will be lost and illiteracy level will continue to rise thereby creating the need to investigate the influence of local community intervention measures on reconstruction of public teacher training colleges in South Sudan.

\section{Objectives of the Study}

The study was guided by the following research objectives;

i. to determine the influence of local community intervention measures on reconstruction of public teacher training colleges in South Sudan

\section{Literature Review}

\subsection{Overview of Global Post Conflict Reconstruction of Teachers Colleges}

About 50 per cent of the entire population around the world are believed to live in areas and states that are highly affected and prone to conflicts (Nicolai, 2008). Since there exist variations in armed conflicts on the basis of their duration, localization as well as intensity, it is possible that the system of education may be affected in different ways. Studies have been conducted to bring out various dimensions of education system that are affected in a negative way by conflicts particularly as it regards the present inequalities in our societies irrespective of the region, ethnicity or religion. At the same time, not every country that is far hit and affected by conflicts is off track in ensuring that their education systems are reconstructed in line with the Millennium Development Goals. Through the World Bank Group, a total of 13 areas affected by conflicts have been identified and which are being tracked in realization of the goal of Universal primary education. These include countries like Sri Lanka and Colombia (Buckland, 2005).

In some of the organizations, conflict is viewed as a challenge as well as opportunity. This is because post conflict environment can provide an environment for further growth and development of the economies (Buckland 2005; Nicolai 2008). Improving educational policy response in the entire period of conflicts requires an understanding of complex role played by conflicts as far as education system is concerned. Post-conflict reconstruction by use of teacher training programs is an excellent idea since, the program and materials used will often explore life experiences that have shaped the views of the locals (Leach, 2007). The simple deeds of good people can make an enormous difference as well as using the training curriculum to equip the teachers with necessary information and experiences that will help them in handling primary school going children in the learning and healing process after their experiences during the conflict and the war.

\subsection{Influence of Local Community Intervention on Post Conflict Reconstruction of Teacher Training Colleges}

In this study, the local community intervention measures include land allocation, security and supply of teachers for the reconstruction of teacher training colleges in conflict resolution. Angola is one the countries that witnessed lengthy conflicts that ravaged the country, according to Wessells and Monteiro (2001), the conflicts are associated with significant physical and social damage as far as peace is concerned. The biggest group that is affected during the conflicts is those with high poverty rates, women and children. The children take the longest time to heal from the violent experiences that they witnessed and Sardinha (2009) shares that in some Angolan communities, rituals are performed to help in the healing process for the children as well as creating harmony 
among community members. In each of the local communities, there were traditional healers that lead the community in performing the rituals by connecting the spiritual and cultural aspects to the people.

The local community plays an important role as far as coming up with culturally based means of reconstruction and healing. Wessells and Monteiro (2004) state that it is important that a community broadly understands its needs so that it is able to prevent from programs that are well customized and designed for the community. The whole idea behind approaches of reconstruction at the community level is that they ensure that local people are honored, their culture respected and the locals are included in peace building and in post-conflict intervention measures. Wessells (2009) recognizes the value of involving the locals in community reconciliation intervention through dialogue and looking at the root causes of the conflict. The lack of sufficient resources is one of the main reasons for the conflicts especially land, hence peace agreements can only be reached and sustained by re-looking at distribution and ownership of land.

In Burundi, Vervisch, Titeca, Vlassenroot and Braeckman (2013) looked at the role that efforts for reconstructing the community play as far as rebuilding of socially generated capital is concerned. The key focus of the economic and social aspects is on technically structured procedural designs that brings about supply generated and driven demand. The researchers do not advocate for general application of community-based development (CBD), since the value systems, myths and ethos, culture and vices that apply in one community do not apply in another community. As such when looking at the local community to resolve the conflicts, it is important to take adequate account of the nature of the intervention and the challenges posed by the particular post-conflict setting.

In Bosnia, Cox (2001) noted that the state build reconstruction efforts and the international response to civil war frequently centers on a search for new constitutional structures and political institutions. On the ground, however, the challenge of post-conflict reconstruction is not solely, or even primarily, one of constitutional design and as such the solution will not come from changing the constitution. Cox (2001) advocates for the use of community based approaches and use of the international communities like avoiding taking partisan positions, strengthening the electoral system, using international authority to enforce the rules; development of local institutions, engage with the state and no longer appropriate to bypass the state and deal solely with the two entities or other local power structure and needs to improve its institution-building techniques.

The safety teachers play an important role in education sector as shared by Nyakundi 2012). The local communities have a role to play in ensuring that teachers and school-going children are safe in and out of class. The education system in the Northern parts of Kenya has been negatively affected by the conflicts and Kiprop-Marakis, Kipkoech and Ferej (2019) reveal that in conflict reconstruction and intervention, the local communities play a big role in securing the area. Teacher training can be improved through neighboring communities agreeing to land division, participation in inter-clan and inter-cultural activities to bring peace and securing the area. For instance, the communities can allocate land for school buildings, set funds for its infrastructure and promote a culture of peace and cohesion.

A report produced by the Global Initiative on Out-of-School Children shows that the number of children who are not receiving an education in South Sudan is approximated to be at least 2.2 million which represents one of the greatest rates of children who are not in the School worldwide. Some of the factors that have contributed to the deprivation of the children's education include conflict, displacement and the collapse of the economy. Production of this report required joint efforts by UNESCO Institute for Statistics, the ministry of education of South Sudan and UNICEF. The study suggested the need for increased investment in enhancement of data that is required in an education system. This helps in ensuring that evidence based education activities are in place while making sure that out of schools children have been effectively monitored. The study also places more emphasis on schools that have clean source of water, teachers that are well trained as well as availability of sufficient books.

Community-based intervention are aimed at empowering local community groups and institutions by offering direct control of investment decisions, planning of projects, execution and monitoring through a process that emphasizes on the inclusivity of participation and management (Hutzel, 2007). The impact of violent conflict and fragility is devastating and comprehensive on a country's society, economy, and political governance. The effects can be tangible and visible; including civilians being killed and injured and destruction of bridges, wells together with health and education facilities. In such situations, the community has often proven resilient, offering structures for uncertainty and fragility for survival and coping. 


\section{Theoretical Framework}

This study was based on peace-building and conflict prevention theory as postulated by Boutros-Ghali (1992), in "An Agenda for Peace: Preventive Diplomacy, Peace-making and Peace-keeping" (Boutros-Ghali, 1992). This was shortly after the end of the Cold War and at the beginning the era of rapid political and economic liberalization globally. The nature, scale, and proliferation of conflicts was assuming inter/intrastate dimension that however widely undermined development and posed threat to national and regional stability. This had the effect of diverting international attention and the limited resources from more immediate development problems.

'Liberia peace' forms the basis of the approach of peace building and prevention of conflicts around the world and its essence is to ensure that human rights and the law as guiding properties are promoted around the world (Boutros-Ghali, 1992). However, building of peace give priority to establishment of political authority that is not violent so that the past of recovery of the country from post conflict is guided and established and this path includes formation of partnerships with other organizations at a regional level and these help in ensuring that the post conflict efforts of reconstruction are realized.

The theory is relevant in this study as it helps out exploit how regions that have faced prolonged conflicts and wars can rebuild, reconstruct and do recovery of their societies. The national government can come in and help in reconstruction, the local communities will aide in post-conflict reconstruction. Peacekeeping efforts can be adopted using the education system from the basic, elementary and tertiary sectors and change the mind-set of the locals, on top of healing their minds and viewpoints from the experiences they faced during the war.

Thus, the most primary concern of peace building is the establishment of a legitimate government is fundamental in provision of security, avoidance of a relapse into violent conflict and undertaking of long-term, socio-economic reconstruction efforts. This theory will be appropriate in demonstrating the complex linkages between the local community intervention in the reconstruction of teacher colleges in South Sudan.

\section{Conceptual Framework}

The conceptual framework of the study is shown in Figure 1. It is used to illustrate the relationship between post conflict intervention and reconstruction of teacher training colleges.

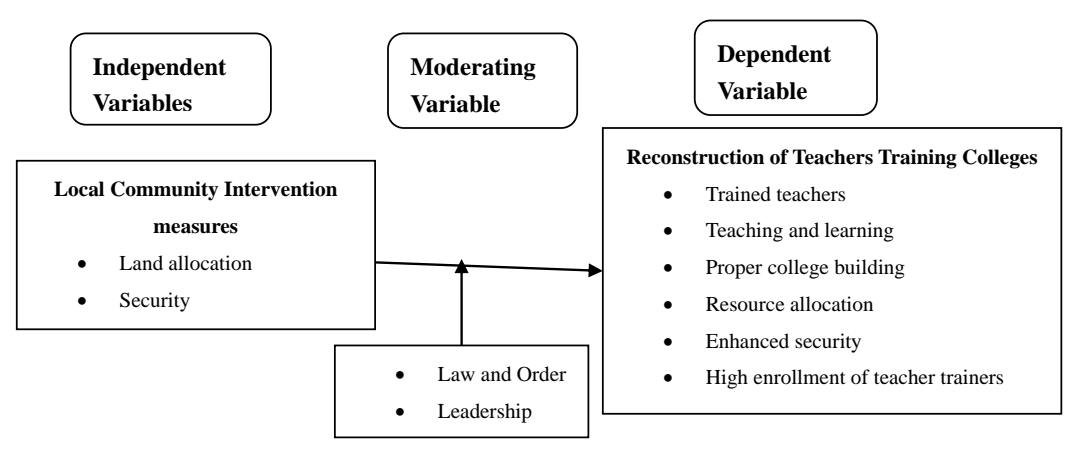

Figure 1. Conceptual framework

\section{Methodology}

This study adopted a descriptive cross-sectional survey design; Donald and Pamela (2003) elucidated that a descriptive study aims at determining the what, when and how of a phenomenon studied. The descriptive cross-sectional survey design was ideal in this study as it was able to create room for the respondents to express their views and opinions of the state of teacher training colleges and the impact they have in post conflict era in South Sudan and its efforts in reconstruction and intervention.

This study targeted three teacher training colleges, 3 principals, 150 tutors and 1800 students registered aned 10 key informants (KIs) comprising of local community representatives making the total target population to be 1963 respondents. 
Table 1. Target population

\begin{tabular}{ll}
\hline Cagetory & Population \\
\hline Student Teachers & 1800 \\
\hline College Tutors & 150 \\
\hline NTTI Principals & 3 \\
\hline Key Informants & 10 \\
\hline Total & $\mathbf{1 9 6 3}$ \\
\hline
\end{tabular}

The study computed a representative sample of 319 using the formula given by Kothari (2004),

$$
\begin{gathered}
\mathrm{n}=\frac{Z^{2} \cdot N \cdot \sigma^{2} \hat{\mathrm{p}}}{(N-1) e^{2}+Z^{2} \partial^{2} \hat{\mathrm{p}}}=\left(1.96^{2} * 1963 * 0.5^{2}\right) /(1963-1) 0.05^{2}+\left(1.96^{2} * 0.5^{2}\right)=1885.2652 / \\
(4.905+0.9604)=1875.6612 / 5.8654
\end{gathered}
$$

$\mathrm{n}=319$

Where; $\mathrm{n}=$ Size of the sample

$\mathrm{N}=$ Size of the population

$\mathrm{e}=$ Acceptable error given as 0.05

$\partial^{2} \hat{\mathrm{p}}=$ the standard deviation of the population and given as 0.5 where not known

$\mathrm{Z}=$ standard variation at a confidence level given as 1.96 at $95 \%$ confidence level.

Sample for student teachers=Total number of teacher students/Population Total*Sample Size

$$
\begin{aligned}
& =(1800 * 319) / 1963 \\
= & 293 \text { student teachers }
\end{aligned}
$$

The study then purposively selected the remaining 26 respondents (319-293) as follows: 20 tutors, 1 NTTI principle and 5 Key Informants KIs. Therefore, at the end of the selection process, a total of 319 respopndents were selected and included in the sample of the study as shown in Table 2.

Table 2. Sample size of student teachers

\begin{tabular}{llll}
\hline Category & Population & Sample Proportion & Sample Size \\
\hline Student Teachers & 1800 & Random Sampling & 293 \\
\hline College Tutors & 150 & Purposive & 20 \\
\hline NTTI Principals & 3 & Purposive & 1 \\
\hline Key Informants & 10 & Purposive & 5 \\
\hline Total & $\mathbf{1 9 6 3}$ & & $\mathbf{2 9 3}$ \\
\hline
\end{tabular}

Pilot test was carried out to ascertain data validity and reliability. For testing content validty, efforts were made to ensure that the piloted instruments are fully scrutinized so as to ensure that they were as valid and reliable as possible. Face validity confirmed the coverage of all the areas of investigation by checking the questionnaire and by adopting already tested instruments used by similar studies. The study had a pilot group of 30 respondents who were was used to test the reliability of the research instrument. This study used Cronbach's Alpha (Cronbach, 1951) in the effort to gauge and establish whether the instruments of the study are reliable enough. High Alpha coefficients values are more reliable. The reliability coefficient of 0.70 or greater is considered acceptable reliability (Nunnally \& Bernstein, 1994). According to Mugenda (2008), more than 0.80 indicates a high degree of reliability. The results of the Cronbach Alpha coefficients as computed from these questionnaires are indicated in Table 3. 
Table 3. Reliability results

\begin{tabular}{lll}
\hline Variable & Cronbach Alpha Coefficient & Comment \\
\hline Local community intervention measures & 0.920 & Reliable \\
\hline Reconstruction of public teacher training colleges & 0.886 & Reliable \\
\hline
\end{tabular}

Descriptive statistics were used to describe the data of the study, provide simple summaries about the data that was gathered and the measures undertaken. More specifically, the study used frequencies and percentages as the descriptive statistics. The frequencies and percentages were used in carrying out an analysis of the general information of the respondents as well as the independent and the dependent variables of the study.

Regression analysis was used to determine the interaction between the study variables was explored by use of regression analysis. A number of outputs were generated and interpreted in the regression analysis process including the model summary, the ANOVA and the beta coefficient table. The proportionate variability in the dependent variable explained by variability in the independent study variables was modeled and explored with the aid of R square. For ruling out whether the study model was significant in predicting the link between one or more variables, F test was adopted and used in the study (Mertler \& Reinhart, 2016).

\section{Data Analysis}

\subsection{Instrument Return Rate}

The study issued out 319 research instruments to 293 student teachers, 20 college tutors, 1 NTTI principal among public teacher training colleges in South Sudan and 5 key informants. The study received 304 dully filled research instruments which represented a response rate of 95.3 per cent. A breakdown of these 304 instruments that were returned having been dully filled is as follows: student teachers 279 (91.8 per cent), college tutors 20(6.6 per cent) and NTTI principal $1(0.329$ per cent) and 4 (1.32 per cent) KIs responded. This response was supported by Mugenda and Mugenda (2003) who noted that response rates of over 70 per cent are deemed to be sufficient for presentation of the results.

\subsection{Reconstruction of Public Teacher Training Colleges}

8.2.1 Reconstruction of Public Teacher Training Colleges' as Shared by Student Teachers

The results are summarized in Table 4.

Table 4. Institutional rating towards reconstruction of public teacher training colleges' as shared by student teachers

\begin{tabular}{lllllllllll}
\hline & Not Effective & \multicolumn{2}{l}{ Ineffective } & \multicolumn{2}{l}{ Effective } & \multicolumn{2}{c}{ Very effective } & \multicolumn{2}{l}{ Total } \\
\hline & f & \% & f & $\mathbf{\%}$ & f & \% & f & \% & f & \% \\
\hline Local Community & 41 & 14.7 & 36 & 12.9 & 114 & 40.9 & 88 & 31.5 & $\mathbf{2 7 9}$ & $\mathbf{1 0 0}$ \\
\hline
\end{tabular}

As shown in Table 4, majority of the respondents 40.9 per cent said that the local community all collectively play an effective role towards reconstruction of public teacher training colleges' respectively.

\subsubsection{Reconstruction of Public Teacher Training Colleges' as Shared by College Tutors}

The findings on reconstruction of public teacher training colleges as shared by the college tutors show that 65 per cent of the respondents said that there was very effective improvement in quality of trained teachers while 75 percent said that there was very effective improvement in college buildings. The other 60 percent of the respondents said that there was very effective improvement in quality of teaching in primary school, 60 percent indicated very effective increase in resource allocation to colleges, 65 percent indicated very effective enhancement of enhanced security around the colleges, 75 percent said there was very effective increment in enrollment of teacher trainers while 55 percent indicated very effective availability of teaching and learning resources. These are shown in Table 5. 
Table 5. Reconstruction of public teacher training colleges as shared by college tutors

\begin{tabular}{llccccccccc}
\hline & Not Effective & \multicolumn{2}{c}{ Ineffective } & \multicolumn{2}{c}{ Effective } & Very Effective & \multicolumn{2}{c}{ Total } \\
\hline & $\mathbf{f}$ & $\mathbf{\%}$ & $\mathbf{f}$ & $\mathbf{\%}$ & $\mathbf{f}$ & $\mathbf{\%}$ & $\mathbf{f}$ & $\mathbf{\%}$ & $\mathbf{f}$ & $\mathbf{\%}$ \\
\hline $\begin{array}{l}\text { Improved quality of trained } \\
\text { teachers }\end{array}$ & 1 & 5 & 1 & 5.0 & 5 & 25.0 & 13 & 65.0 & $\mathbf{2 0}$ & $\mathbf{1 0 0}$ \\
\hline $\begin{array}{l}\text { Improved/Proper } \\
\text { building }\end{array}$ & 1 & 5 & 1 & 5.0 & 3 & 15.0 & 15 & 75.0 & $\mathbf{2 0}$ & $\mathbf{1 0 0}$ \\
\hline $\begin{array}{l}\text { Improved quality of teaching } \\
\text { in primary school }\end{array}$ & 1 & 5 & 1 & 5.0 & 6 & 30.0 & 12 & 60.0 & $\mathbf{2 0}$ & $\mathbf{1 0 0}$ \\
\hline $\begin{array}{l}\text { Increased resource allocation } \\
\text { to colleges }\end{array}$ & 1 & 5 & 2 & 10.0 & 5 & 25.0 & 12 & 60.0 & $\mathbf{2 0}$ & $\mathbf{1 0 0}$ \\
\hline $\begin{array}{l}\text { Enhanced security } \\
\text { the colleges }\end{array}$ & 1 & 5 & 1 & 5.0 & 5 & 25.0 & 13 & 65.0 & $\mathbf{2 0}$ & $\mathbf{1 0 0}$ \\
\hline $\begin{array}{l}\text { High enrollment of teacher } \\
\text { trainers }\end{array}$ & 1 & 5 & 1 & 5.0 & 3 & 15.0 & 15 & 75.0 & $\mathbf{2 0}$ & $\mathbf{1 0 0}$ \\
\hline $\begin{array}{l}\text { Availability of teaching and } \\
\text { learning resource }\end{array}$ & 2 & 10 & 2 & 10.0 & 5 & 25.0 & 11 & 55.0 & $\mathbf{2 0}$ & $\mathbf{1 0 0}$ \\
\hline
\end{tabular}

\subsubsection{Reconstruction of Public Teacher Training Colleges' as Shared by Principal}

The study established some statements on the indicators of re-constructed Public Primary Teachers Training Colleges and the principals were asked to indicate their rating on these statements. A four point scale was used covering effective, not effective, ineffective and very effective. From the findings, the quality of trained teachers was effective; there was effectiveness in improvement of college building while the resources allocated to the school were not effective. It was further noted that there was effective enhancement of security by all actors, high enrolment of the teacher trainers while the availability of adequate teaching and learning was not adequate.

\subsubsection{Reconstruction of Public Teacher Training Colleges' as per Key Informants}

The KIs were asked to indicate how they could rate the number of primary teacher college in South Sudan on a scale of 1 to 10. The KIs noted that although there existed a total of 7 primary teacher colleges in South Sudan, only 3 of these were functional. It was noted that the previous political instability in the country could be attributed to nonfunctional teacher training colleges in South Sudan. This inadequacy of the teacher training colleges could be an indication of why the other stakeholders like the local community was to come in so as to bridge the gap.

From the findings, one of the KI from the ministry of education shared the role of formulation and implementation of education policies including the overall curricula. The KIs went further and disclosed some of the education policies formulated to include training and remuneration of the teachers as well as ensuring the schools were well equipped with infrastructures including the computer labs. The other KIs from the humanitarian organizations shared the role played in reconstruction of the teacher colleges to include liaising with donors for the sake of funding and organization of capacity building programs to the teachers.

\subsection{Data Analysis on Local Community Intervention Measures and Reconstruction of Public Teacher Training Colleges}

The results of the analysis as shared by the tutors and student teachers as well as the principal are indicated in subsequent sections.

\subsection{Tutors and Student Teachers Views on Local Community Intervention Measures}

The results were summarized and presented in Table 6 . 
Table 6. Student teachers views on local community intervention measures

\begin{tabular}{lll}
\hline & Frequency & Percentage \\
\hline Fair & 22 & 7.9 \\
\hline Good & 188 & 67.4 \\
\hline Excellent & 69 & 24.7 \\
\hline Total & $\mathbf{2 7 9}$ & $\mathbf{1 0 0}$ \\
\hline
\end{tabular}

From Table 6, most of the respondents 67.4 per cent said that local community intervention measures were good in reconstruction of public teacher training college in South Sudan.

Table 7. Tutors' views on local community intervention measures

\begin{tabular}{lll}
\hline & Frequency & Percentage \\
\hline Fair & 2 & 10 \\
\hline Good & 13 & 65 \\
\hline Excellent & 5 & 25 \\
\hline Total & $\mathbf{2 0}$ & $\mathbf{1 0 0}$ \\
\hline
\end{tabular}

From Table 7, majority 65.0 percent of the tutors were of the opinion that local community intervention were good in primary teacher colleges' the reconstruction in South Sudan. Community leadership is involved in management and learning of schools which promote more accountability and sense of ownership.

Table 8. Local community intervention measures according to student teachers

\begin{tabular}{|c|c|c|c|c|c|c|c|c|c|c|}
\hline & \multicolumn{2}{|c|}{ Not Effective } & \multicolumn{2}{|c|}{ Ineffective } & \multicolumn{2}{|c|}{ Effective } & \multicolumn{2}{|c|}{ Very Effective } & \multicolumn{2}{|c|}{ Total } \\
\hline & $\mathbf{f}$ & $\%$ & $\mathbf{f}$ & $\%$ & $\mathbf{f}$ & $\%$ & $\mathbf{f}$ & $\%$ & $\mathbf{f}$ & $\%$ \\
\hline $\begin{array}{l}\text { Management of } \\
\text { colleges }\end{array}$ & 3 & 1.1 & 20 & 7.2 & 151 & 54.1 & 105 & 37.6 & 279 & 100 \\
\hline $\begin{array}{ll}\text { Supply of } \\
\text { volunteered } \\
\text { casual labour }\end{array}$ & 7 & 2.5 & 15 & 5.4 & 142 & 50.9 & 115 & 41.2 & 279 & 100 \\
\hline $\begin{array}{l}\text { Provision of } \\
\text { In-kind support to } \\
\text { the colleges }\end{array}$ & 5 & 1.8 & 19 & 6.8 & 139 & 49.8 & 116 & 41.6 & 279 & 100 \\
\hline $\begin{array}{l}\text { Provision of local } \\
\text { security }\end{array}$ & 14 & 5.0 & 23 & 8.2 & 134 & 48.0 & 108 & 38.7 & 279 & 100 \\
\hline $\begin{array}{l}\text { Fundraising for } \\
\text { colleges }\end{array}$ & 10 & 3.6 & 17 & 6.1 & 146 & 52.3 & 106 & 38.0 & 279 & 100 \\
\hline
\end{tabular}

Table 8 shows that 54.1 per cent of the respondents said the engagement of colleges by the community was effective, 50.9 percent cited that supply of volunteered casual labour was effective, 49.8 per cent noted that provision of in-kind support to the colleges by the community was effective while 48.0 per cent cited provision of local security and 52.3 percent indicated that fundraising for colleges was effective. From the results in Table 7 , it can be inferred that the local community is very effective in reconstruction of teacher training colleges. Vervisch, Titeca, Vlassenroot and Braeckman (2013) looked at community based reconstruction as an avenue for rebuilding social capital after a long period of conflicts.

On the basis of security, the colleges for training teachers may be considered and recognized as insecure and unstable due to a number of reasons. Colleges and campus are used to house students that are active politically as 
well as the academicians that play a key role in initiation of movements and protests in political horizons (Thyne 2006; Zeilig 2007; Gill and DeFronzo 2009).

Table 9. Local community intervention measures according to tutors

\begin{tabular}{lllllllllll}
\hline & \multicolumn{2}{l}{ Not Effective } & \multicolumn{2}{l}{ Ineffective } & \multicolumn{2}{l}{ Effective } & \multicolumn{2}{c}{ Very Effective } & \multicolumn{2}{c}{ Total } \\
\hline & $\mathbf{f}$ & $\mathbf{\%}$ & $\mathbf{f}$ & $\mathbf{\%}$ & $\mathbf{f}$ & $\mathbf{\%}$ & $\mathbf{f}$ & $\mathbf{\%}$ & $\mathbf{f}$ & $\mathbf{\%}$ \\
\hline Management of colleges & 2 & 10.0 & 7 & 35.0 & 9 & 45.0 & 2 & 10.0 & $\mathbf{2 0}$ & $\mathbf{1 0 0}$ \\
\hline $\begin{array}{l}\text { Supply of volunteered } \\
\text { casual labour }\end{array}$ & 1 & 5.0 & 6 & 30.0 & 10 & 50.0 & 3 & 15.0 & $\mathbf{2 0}$ & $\mathbf{1 0 0}$ \\
\hline $\begin{array}{l}\text { Provision of In-kind } \\
\text { support to the colleges }\end{array}$ & 2 & 10.0 & 1 & 5.0 & 13 & 65.0 & 4 & 20.0 & $\mathbf{2 0}$ & $\mathbf{1 0 0}$ \\
\hline Provision of local security & 2 & 10.0 & 3 & 15.0 & 7 & 35.0 & 8 & 40.0 & $\mathbf{2 0}$ & $\mathbf{1 0 0}$ \\
\hline Fundraising for colleges & 2 & 10.0 & 3 & 15.0 & 10 & 50.0 & 5 & 25.0 & $\mathbf{2 0}$ & $\mathbf{1 0 0}$ \\
\hline
\end{tabular}

The study noted that 45.0 percent of the tutors were of the view that the management of colleges was effective, 50 percent indicated that supply of volunteered casual labour was effective, 65 per cent noted that provision of in-kind support to the colleges was effective, 40 per cent indicated that provision of local security was very effective while 50 percent said that fundraising for colleges was adequate.

Table 10. Perceptions of student teachers on local community initiatives intervention measures

\begin{tabular}{lllllllllll}
\hline & Not available & \multicolumn{2}{c}{ Inadequate } & \multicolumn{2}{c}{ adequate } & \multicolumn{2}{c}{ Very adequate } & \multicolumn{2}{c}{ Total } \\
\hline & $\mathbf{f}$ & $\mathbf{\%}$ & $\mathbf{f}$ & $\mathbf{\%}$ & $\mathbf{f}$ & $\mathbf{\%}$ & $\mathbf{f}$ & $\mathbf{\%}$ & $\mathbf{f}$ & $\mathbf{\%}$ \\
\hline $\begin{array}{l}\text { Allocation of land to } \\
\text { construct colleges }\end{array}$ & 10 & 3.6 & 33 & 11.8 & 151 & 54.1 & 85 & 30.5 & $\mathbf{2 7 9}$ & $\mathbf{1 0 0}$ \\
\hline $\begin{array}{l}\text { Provision of security } \\
\text { to colleges }\end{array}$ & 19 & 6.8 & 13 & 4.7 & 135 & 48.4 & 112 & 40.1 & $\mathbf{2 7 9}$ & $\mathbf{1 0 0}$ \\
\hline $\begin{array}{l}\text { Supply of volunteer } \\
\text { teachers to support } \\
\text { colleges }\end{array}$ & 19 & 6.8 & 30 & 10.8 & 134 & 48.0 & 96 & 34.4 & $\mathbf{2 7 9}$ & $\mathbf{1 0 0}$ \\
\hline $\begin{array}{l}\text { Supply of learners to } \\
\text { colleges }\end{array}$ & 24 & 8.6 & 13 & 4.7 & 154 & 55.2 & 88 & 31.5 & $\mathbf{2 7 9}$ & $\mathbf{1 0 0}$ \\
\hline $\begin{array}{l}\text { Provision of housing } \\
\text { for } \\
\text { teachers volunteer }\end{array}$ & 17 & 6.1 & 27 & 9.7 & 139 & 49.8 & 96 & 34.4 & $\mathbf{2 7 9}$ & $\mathbf{1 0 0}$ \\
\hline $\begin{array}{l}\text { Provision of food for } \\
\text { college community }\end{array}$ & 3 & 1.1 & 19 & 6.8 & 59 & 21.1 & 198 & 71.0 & $\mathbf{2 7 9}$ & $\mathbf{1 0 0}$ \\
\hline
\end{tabular}

Table 10 shows that most of the highest values of percentages fall in the column of adequate; which mean that majority of the respondents rated the various statements provided under on local community initiatives intervention measure as adequate. More specifically, 54.1 per cent of the respondents said that the community helped in allocation of land to construct colleges, 48.4 per cent indicated provision of security to colleges, 48.0 per cent noted supply of volunteer teachers to support colleges, 55.2 per cent indicated the supply of learners to colleges, 49.8 per cent suggested provision of housing for volunteer teachers while an overwhelming 71 per cent said that the provision of food for college community was very adequate. 
Table 11. Perceptions of student teachers on local community initiatives intervention

\begin{tabular}{llllllllllll}
\hline & Not available & \multicolumn{2}{l}{ Inadequate } & \multicolumn{2}{c}{ adequate } & \multicolumn{2}{c}{ Very adequate } & \multicolumn{2}{c}{ Total } \\
\hline & $\mathbf{f}$ & $\mathbf{\%}$ & $\mathbf{f}$ & $\mathbf{\%}$ & $\mathbf{f}$ & $\mathbf{\%}$ & $\mathbf{f}$ & $\mathbf{\%}$ & $\mathbf{f}$ & $\mathbf{\%}$ \\
\hline $\begin{array}{l}\text { Allocation of land to } \\
\text { construct colleges }\end{array}$ & 1 & 5.0 & 3 & 15.0 & 12 & 60.0 & 4 & 20.0 & $\mathbf{2 0}$ & $\mathbf{1 0 0}$ \\
\hline $\begin{array}{l}\text { Provision of security to } \\
\text { colleges }\end{array}$ & 2 & 10.0 & 3 & 15.0 & 10 & 50.0 & 5 & 25.0 & $\mathbf{2 0}$ & $\mathbf{1 0 0}$ \\
\hline $\begin{array}{l}\text { Supply of volunteer } \\
\text { teachers to support } \\
\text { colleges }\end{array}$ & 5.0 & 2 & 10.0 & 11 & 55.0 & 6 & 30.0 & $\mathbf{2 0}$ & $\mathbf{1 0 0}$ \\
\hline $\begin{array}{l}\text { Supply of learners to } \\
\text { colleges }\end{array}$ & 2 & 10.0 & 3 & 15.0 & 10 & 50.0 & 5 & 25.0 & $\mathbf{2 0}$ & $\mathbf{1 0 0}$ \\
\hline $\begin{array}{l}\text { Provision of housing for } \\
\text { volunteer teachers }\end{array}$ & 2 & 10.0 & 3 & 15.0 & 13 & 65.0 & 2 & 10.0 & $\mathbf{2 0}$ & $\mathbf{1 0 0}$ \\
\hline $\begin{array}{l}\text { Provision of food for } \\
\text { college community }\end{array}$ & 1 & 5.0 & 4 & 20.0 & 3 & 15.0 & 12 & 60.0 & $\mathbf{2 0}$ & $\mathbf{1 0 0}$ \\
\hline
\end{tabular}

The findings indicate that 60.0 percent of the respondents shared that allocation of land to construct colleges was adequate, 50 percent said that provision of security to colleges was adequate, 55 percent said that the supply of volunteer teachers to support colleges, 50 per cent indicated that supply of learners to colleges was adequate, 65 percent noted that provision of housing for volunteer teachers was adequate and 60 percent of the tutors were of the view that provision of food for college community was very adequate.

\subsection{Principal's Views on Local Community Intervention Measures as Shared by the Principal}

The principal was provided with a questionnaire that sought to rate the local community initiatives intervention measures on primary teachers' colleges' reconstruction. From the findings, the study revealed that supply of learners, provision of casual labor, provision of security around colleges, provision of land construction colleges and involvement in the management of colleges were adequate as far as reconstruction of teacher training colleges was concerned.

\subsection{Key Informants' Views on Local Community Intervention Measures}

The KIs were asked to suggest some of the mobilization strategies that they felt the local community could employ to help in reconstruction of primary teacher colleges. One of the KIs noted that creation of awareness to the local community to take their children to teacher training colleges could go a long way to reconstruction of the public teacher training colleges in South Sudan. Another KI said that the local community could give out land for construction of the classrooms and other facilities including the playgrounds and this would contribute towards reconstruction of public teacher training colleges in South Sudan.

\subsection{Regression Results and Hypotheses Testing on Local Community Intervention Measures}

The study used simple linear regression analysis to test the formulated hypothesis and the results are as shown in subsequent sections.

\section{Model Summary}

The results of the model summary of the study are shown in Table 12 .

Table 12. Model summary

\begin{tabular}{lllll}
\hline Model & R & R Square & Adjusted R Square & Std. Error of the Estimate \\
\hline 1 & $.764^{\mathrm{a}}$ & .584 & .583 & .45482 \\
\hline
\end{tabular}

a. Predictors: (Constant), Local Community Intervention Measures 
From Table 11, the value of the adjusted $\mathrm{R}$ square is 0.583 ; this means that 58.3 per cent variation in reconstruction of public education is explained by local community intervention measures. Therefore, apart from local community intervention measures, there are also other factors with an influence on reconstruction on public teacher training college in South Sudan which further studies should be done to establish.

\section{Analysis of Variance}

The ANOVA results are summarized in Table 12 and they helped in determining the overall significance of the study model.

Table 13. Analysis of variance

\begin{tabular}{llllll}
\hline & Sum of Squares & df & Mean Square & F & Sig. \\
\hline Regression & 86.676 & 1 & 86.676 & 419.012 & $.000^{\mathrm{b}}$ \\
\hline Residual & 61.644 & 298 & .207 & & \\
\hline Total & $\mathbf{1 4 8 . 3 2 0}$ & $\mathbf{2 9 9}$ & & & \\
\hline
\end{tabular}

a. Dependent Variable: Reconstruction of Public Teacher Training Colleges

b. Predictors: (Constant), Local Community intervention Measures

The results in Table 13 show that the model of the study was significant and thus suitable for use in the study. The p-value is less than 0.05 which support the assertion that local intervention measures have significant effect on reconstruction of teacher training college in South Sudan.

\section{Regression Coefficients and Beta}

The results of the beta coefficients and the significance was used to test the formulated hypothesis are indicated in Table 14.

Table 14. Regression coefficients and beta

\begin{tabular}{|c|c|c|c|c|c|}
\hline & Unstan & zed Coefficients & Standardized Coefficients & & \\
\hline & $\overline{\mathbf{B}}$ & Std. Error & Beta & $\mathbf{t}$ & Sig. \\
\hline (Constant) & 11.671 & .303 & & 38.582 & .000 \\
\hline $\begin{array}{l}\text { Local Community Intervention } \\
\text { Measures }\end{array}$ & .178 & .009 & .764 & 20.470 & .000 \\
\hline
\end{tabular}

From Table 14, the following regression equation is predicted:

$$
\mathrm{Y}=11.671+.178 \mathrm{X}_{1}
$$

The last objective of the study was to determine the influence of local community intervention measures on reconstruction of public teacher training colleges in South Sudan. From the results, it was shown that when the local community intervention measures are held constant, re-construction of public teacher training colleges in South Sudan would be at 11.671. A unit change in local community intervention measures when other factors are held constant would result into 0.178 unit increase in re-construction of public teacher training colleges in South Sudan.

The study tested the following hypotheses: local community intervention do not significantly influence the reconstruction of public teacher training colleges in South Sudan. At 5 per cent level of significance, the study noted that local community intervention measures has p-value of 0.000 which is lower than 0.05 . This means that local community intervention measures have significant effect on reconstruction of public teacher training colleges. The study therefore rejects the formulated hypothesis $\mathrm{H}_{1}$ : Local community intervention do not significantly influence reconstruction of public teacher training colleges in South Sudan. 


\section{Correlation Results}

Correlation analysis was conducted to determine the interaction between the variables of the study. Usually, correlation analysis is useful when the study seeks to determine how variables (independent) relate with the other (dependent) variable (Field, 2005). Table 14 shows the correlation coefficients for local community intervention measures and reconstruction of public primary teachers colleges. The results are as summarized in Table 15.

Table 15. Correlation results

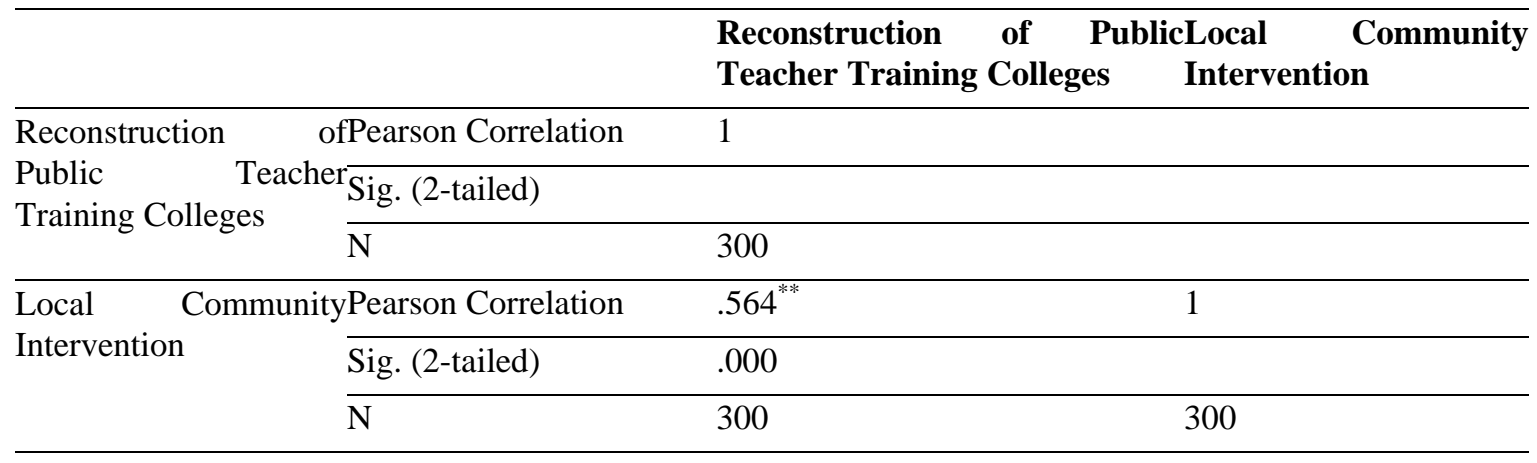

Correlation values (off-diagonal elements) of at least 0.9 are sometimes interpreted as indicating a multicollinearity problem (Hair et al., 1998). From the results, the correlations are below 0.9. Therefore, the study variables were not highly correlated as to cause multicollinearity. The study established that local community intervention $(\mathrm{r}=0.564)$ had positive correlation with reconstruction of public teacher training colleges. For effective conflict intervention through using the education system; there is need to focus on training of teachers as the driver of the education system and as the ones who will ensure effective education system that yields positive results.

\section{Conclusion and Recommendations}

\subsection{Conclusions}

The study set to determine the influence of local community intervention measures on primary teachers' colleges reconstruction in South Sudan. Hypothesis $\mathrm{H}_{4}$ was tested by regressing local community intervention measures on primary teachers' colleges reconstruction in South Sudan. The results indicated that the combined effect of land allocation, security and supply of teachers and students plays very critical role on reconstruction of primary teacher colleges' in South Sudan. The study thus concluded that local community intervention measures significantly influence reconstruction of primary teachers' colleges reconstruction. The community has a great role to play in reconstruction of education in emergencies. Parents and community should be respected partners in the process of rebuilding primary education where community resources would be included as part of required facilities. In Nigeria, implementation of Universal Basic Education scheme heavily depended on the community. The community was expected to offer logistics support and enabling environment for the execution of the scheme in the localities.

\subsection{Recommendations From the Study}

Based on the findings, the study made the following recommendations:

i. The ministry of general education and instruction in South Sudan ought to work in close collaboration with all the stakeholders in the field of education as far as reconstruction of training colleges is concerned.

ii. There is need for the ministry of general education and instruction in South Sudan to immediately renovate the destroyed colleges and construction more across the country to support the need for quality education.

iii. The local community of South Sudan should actively support the reconstruction of public teacher training colleges in the country as this is one of the basic functions of any national government in the country. 
iv. Further consideration of Pearson Correlation results imply that the local community is playing an important role in reconstruction efforts of teacher training in South Sudan and these efforts should be even be doubled.

\section{References}

Ajieng, M. M. M. (2018). Contributions of diplomatic approaches in resolving conflicts over the River Nile water resources among the Member States of The Nile Basin Initiative (A Case of South Sudan 2011-2016). Doctoral dissertation.

Al-Salem, W., Herricks, J. R., \& Hotez, P. J. (2016). A review of visceral leishmaniasis during the conflict in South Sudan and the consequences for East African countries. Parasites \& Vectors, 9(1), 460. https://doi.org/10.1186/s13071-016-1743-7

Barakat, S. (2016). The failed promise of multi-donor trust funds: aid financing as an impediment to effective state-building in post-conflict contexts. Policy Studies, 30(2), 107-126. https://doi.org/10.1080/01442870902723485

Boyle-Baise, M., \& Sleeter, C. E. (2000). Community-based service learning for multicultural teacher education. The Journal of Educational Foundations, 14(2), 33.

Bruch, C., Muffett, C., \& Nichols, S. S. (2016). Natural resources and post-conflict governance: Building a sustainable peace. Governance, Natural Resources and Post-Conflict Peacebuilding, 1-32. https://doi.org/10.4324/9780203109793-1

Cox, M. (2001). State building and post-conflict reconstruction: Lessons from Bosnia. Geneva: Centre for Applied Studies in International Negotiations, 3-28.

Donald, K. K., \& Delno, L. A. (2006). Proposal and thesis writing. Paulines Publications.

Education for All Global Monitoring Report. (2011). Seeing the Reconstruction of Primary Education in 2009-2009. Juba.

Human Rights Watch. (2015). World Report 2015: Yemen.

Hutzel, K. (2007). Reconstructing a community, reclaiming a playground: A participatory action research study. Studies in Art Education, 48(3), 299-315. https://doi.org/10.1080/00393541.2007.11650107

Johnson, I. M. (2016). Foreign intervention and domestic initiatives in the development of education for librarianship and information management, with Iraq as a Case Study. Doctoral dissertation, Robert Gordon University.

Kiprop-Marakis, J., Kipkoech, L., \& Ferej, A. K. (2019). Effect of ethnic conflicts on teachers instructional performance in public secondary schools in lower areas of Baringo County, Kenya. European Journal of Education Studies.

Kusago, T. (2019). Post-disaster community recovery and community-based collaborative action research-A case of process evaluation method for community life improvement. In Innovation beyond technology (pp. 195-221). Springer, Singapore. https://doi.org/10.1007/978-981-13-9053-1_9

Lansford, J. E., Dodge, K. A., Pettit, G. S., \& Bates, J. E. (2016). A public health perspective on school dropout and adult outcomes: A prospective study of risk and protective factors from age 5 to 27 years. Journal of Adolescent Health, 58(6), 652-658. https://doi.org/10.1016/j.jadohealth.2016.01.014

Lasater, K. (2016). Parent-teacher conflict related to student abilities: the impact on students and the family-school partnership. School Community Journal, 26(2), 237-262.

Leach, F. (2007). Education, conflict and reconciliation: International perspectives. Peter Lang.

Lewis, J. (1996). Angola 1995: The road to peace. International Relations, 13(1), 81-98. https://doi.org/10.1177/004711789601300105

Loh, C. Y. R., \& Teo, T. C. (2016). Students' perception of collaborative learning, conflict management and satisfaction in a private educational institution learning environment: an Asian case study. Journal of Education \& Social Policy, 3(3), 72-79.

Milton, S., \& Barakat, S. (2016). Higher education as the catalyst of recovery in conflict-affected societies. Globalisation, Societies and Education, 14(3), 403-421. https://doi.org/10.1080/14767724.2015.1127749

Ministry of Education. (1997). Study of education sector in Rwanda. Kigali.

Mugenda, O., \& Mugenda, G. A. (2003). Research methods; qualitative and quantitative. Nairobi: Acts Press. 
Nicolai, S. (2008). Opportunities for change: Education innovation and reform during and after conflict. Paris: UNESCO.

Nyakundi, O. (2012). Implementation of safety standards and guidelines in public secondary schools in Marani District, Kisii County, Kenya. Kenyatta University.

Pherali, T., \& Sahar, A. (2018). Learning in the chaos: A political economy analysis of education in Afghanistan. Research in Comparative and International Education, 13(2), 239-258. https://doi.org/10.1177/1745499918781882

Piplani, V., \& Talmadge, C. (2016). When war helps civil-military relations: Prolonged interstate conflict and the reduced risk of coups. Journal of Conflict Resolution, 60(8), 1368-1394. https://doi.org/10.1177/0022002714567950

Republic of South Africa, South African Schools Act. (1996). Act No. 84 of 1996.

Rubagiza, J., Umutoni, J., \& Kaleeba, A. (2016). Teachers as agents of change: promoting peace building and social cohesion in schools in Rwanda. Education as Change, 20(3), 202-224. https://doi.org/10.17159/1947-9417/2016/1533

Sardinha, J. (2009). Immigrant associations, integration and identity: Angolan, Brazilian and Eastern European communities in Portugal (p. 340). Amsterdam University Press. https://doi.org/10.5117/9789089640369

Schauer, S. G., Hill, G. J., Naylor, J. F., April, M. D., Borgman, M., \& Bebarta, V. S. (2018). Emergency department resuscitation of pediatric trauma patients in Iraq and Afghanistan. The American Journal of Emergency Medicine, 36(9), 1540-1544. https://doi.org/10.1016/j.ajem.2018.01.014

Smidt, H. M. (2020). United Nations peacekeeping locally: enabling conflict resolution, reducing communal violence. Journal of Conflict Resolution, 64(2-3), 344-372. https://doi.org/10.1177/0022002719859631

Smith, A. (2005). Education in the twenty-first century: Conflict, reconstruction and reconciliation. Compare: A Journal of Comparative and International Education, 35(4), 373-391. https://doi.org/10.1080/03057920500331397

UNESCO. (2010). Education for all Global Monitoring Report 2010: Reaching the Marginalized. Paris: UNESCO.

UNICEF. (2015, October 5). Education in emergencies and post-crisis transition. Retrieved from http://www.unicef.org/education/bege_61685.html

USAID. (2015). Teacher development and management in South Sudan. Juba.

Vervisch, T., Titeca, K., Vlassenroot, K., \& Braeckman, J. (2013). Social capital and post-conflict reconstruction in burundi: the limits of community-based reconstruction. Development and Change, 44(1), 147-174. https://doi.org/10.1111/dech.12008

Wessells, M. (2009). Community reconciliation and post-conflict reconstruction for peace. In Handbook on building cultures of peace (pp. 349-361). Springer, New York, NY. https://doi.org/10.1007/978-0-387-09575-2_24

Wessells, M. G., \& Monteiro, C. (2004). Healing the wounds following protracted conflict in Angola: A community-based approach to assisting war-affected children. Handbook of Culture, Therapy, and Healing, 321-341.

Wessells, M., \& Monteiro, C. (2001). Psychosocial intervention and post-war reconstruction in Angola: Interweaving Western and traditional approaches. Peace, Conflict, and Violence: Peace Psychology for the 21st Century, 262-275.

World Bank. (2012). South Sudan - Paving the way for a secure future: 2012 annual report.

World Bank. (2010). Country Brief: Republic of Congo. January: World Bank.

\section{Copyrights}

Copyright for this article is retained by the author(s), with first publication rights granted to the journal.

This is an open-access article distributed under the terms and conditions of the Creative Commons Attribution license (http://creativecommons.org/licenses/by/4.0/). 